\title{
A Theory of Economic Policy Evaluation in Democratic Poor Countries: Policy Failure and the Paradox of a Majority Vote
}

\author{
Carren Pindiriri \\ University of Zimbabwe \\ pindiriric@gmail.com
}

\begin{abstract}
While public policy evaluation literature extensively debates and evaluates public policy failures and successes, it falls short of tracing the reasons why economic policies derived from Manifestos of the democratically elected governments end up having less support or less successful, irrespective of a majority vote. In order to provide quantitative answers to this paradox, this article presents a theory of the paradox of a majority vote and provides some implications and solutions from the theory. The theory points to the fact that being a democratically elected government with a majority vote does not guarantee successful policies. Policies made by government, despite how good they are, may face greater resistance or opposition from those with influence in the economy thereby leading to policy failure. Two main reasons that may cause a greater resistance to a government policy relative to support are: the existence of a larger number of government opponents within the economic actors' group or a larger weight of opponents in the economy. An opposition with a strong urban support base is likely to provide a major source of friction from more influential supporters in the economy. The key lessons derived from the paradox for reducing incidences of policy failure are: 1) a political dialogue bringing together the main opponents is crucial after every major election. Participants in the dialogue must command a significant share of the electorate in order to have a significant impact, and 2) government policy formulation must be an inclusive process that includes everyone.
\end{abstract}

Key words: policy evaluation, democracy, majority vote, policy failure, policy success 


\section{Introduction}

Regardless of the election Manifestos that lead to victories in national elections, many ruling parties' governments in poor countries subsequently face serious problems of economic policy failure. For example, Zimbabwe has continued to experience serious and potentially fatal damage to macroeconomic policy legitimacy over the past three decades, despite the ruling party's continued domination of the national general elections (see Southall, 2018 and Besada \& Moyo, 2008). Following the hyper-inflation which reached over 2 million percent in 2008 and a growing unsustainable budget deficit, the winning Zimbabwe African National Union Patriotic Front (ZANU-PF) party formed a government of national unity (GNU) with the main opposition parties, the Movement for Democratic Change led by Tsvangirai (MDC-T) and the Movement for Democratic Change led by Ncube (MDC-N), in 2009. The worthless domestic currency was discarded in favour of a multicurrency regime, which included in its basket the US\$, the Rand and the Pula as the major trading currencies. The 5-year period of inclusive government was characterized by price stability, improved fiscal discipline, re-engagement with the international community and positive economic growth averaging 8.1\% (Southall, 2018 and ZIMSTAT, 2013).

During the last years of the GNU, 2012 and 2013, the Government of Zimbabwe faced serious financial problems. By 2013, the Government was almost broke with the Finance Minister reporting that only US\$217 was remaining in the country's coffers after paying civil servants (Minister of Finance, 2013). During the 2013 general election, ZANU-PF won resoundingly and resumed monopoly control of the economy. The Government continued to face serious challenges which included high levels of unemployment, fiscal indiscipline and cash shortages, among others. In an attempt to address cash challenges, the Reserve Bank of Zimbabwe introduced bond notes in 2016 backed by the US\$200 million loan from Afrexim bank. However, this guarantee was violated as the central bank announced to increase the issue to US\$500 million bond notes equivalent in August 2017. Cash shortages, however, continued thereby promoting the growth of electronic transfers, with real time gross settlements (RTGs) accounting for over \$2 billion by end of 2017 (RBZ, 2018). Despite maintaining the official bond value at one to one parity with the US\$, the market value of the bond note continued to depreciate as demonstrated by the black market rate. The economy collapsed and in November 2017, the military joined forces with civilians to dislodge the then President, Robert Mugabe, from power. The general election of July 2018 saw ZANU-PF winning resoundingly again under the new leadership and retaining the monopoly of controlling the economy. A new currency, the RTGS\$, was introduced in 2019 with its value determined by market forces. Subsequently, the domestic currency depreciated further causing prices to skyrocket. By June 2019, inflation level banged figures above 90 percent (ZIMSTAT, 2019). All these developments led to weak preference of the domestic currency or its rejection in some markets and destruction of incomes and savings. The introduced interbank market for foreign exchange failed to live up to expectations as most economic agents abandon the interbank market in 
preference of the black market. Acute shortages of foreign currency continued to persist as little foreign currency find its way to the interbank (Sibanda, 2019).

Similar situations, where policies implemented by the ruling party failed irrespective of garnering a majority vote, have been common in a number of poor countries. For instance, the Government of Zambia faced the same situation during the Kaunda era when it started to lose urban support during the early 90s as a result of serious macroeconomic problems. Poverty increased and the country saw a transition from a middle-income economy to a least developed country as a result of low copper prices, inflexible and state-controlled economic policies (UNDP, 2010). In the general elections of 1991, the opposition led by Frederick Chiluba finally won the general election. Likewise, in Uganda when Yoweri Museveni was re-elected in February 2011 for a fourth consecutive term, garnering $68 \%$ of the votes, inflation skyrocketed by October 2011 reaching 30.5\% (UBS, 2011). As a result, Ugandans protested against the high cost of living.

While we expect the winning party with a majority vote to easily push economic policies in its Manifesto to success, due to its relative advantage in support, the reality as in Zimbabwe and other countries demonstrate otherwise. This points to clear paradoxical outcomes. Previous studies on economic and public policy failure have mainly been centered on understanding grey areas in the definition of policy failure, identifying failed policies and causes of their failure emanating from poor policy design and infrastructure (McConnell, 2010; Hill \& Hupe, 2009 and Schneider \& Ingram, 1997) while offering no explanation on why winning political parties in democratic States sometimes fail to make policies in their Manifestos successful, despite garnering a majority vote in national elections. It is against this background that this article aims to interrogate and provide an objective explanation as to why governments with resounding election victories sometimes fail to push policies derived from their winning Manifestos to fruition. In other words, the article explains reasons for the existence of the paradox of a majority vote in policy evaluation.

\section{Brief literature review and context of the theory}

The debate on what constitutes policy failure, policy success and the grey areas in the definitions of policy failure is extensively deliberated in McConnell (2010). According to McConnell (Ibid), extreme protagonists and opposing extremists are keen to claim policy success and policy failure, respectively. The constitution of policy failure and success is sometimes based on political sentiments, that is, the definition of what constitutes policy failure is mainly subjective (Wildavsky, 1987). For instance, some political actors may claim policies implemented by an opponent as failure while supporters may claim same policies as successful (Fischer, 2003). Policy failures and successes are well documented in a number of studies (see Southall, 2018; Howlett et al., 2015; Hindmoor \& McConnell, 2013; McConnell, 2010; Gupta \& Sathye, 2009; Handmer \& Dovers, 2007; Pollack, 2007; Walsh, 2006 and Dunleavy, 1995). McConnell (2010), however, argues that policy outcomes are usually in-between what opponents claim as failure and what protagonists claim as success. In this article, the success of a policy is 
indicated by the achievement of the set goals. Policies are formulated with the aim of achieving certain target goals. So, when these goals are not achieved then the policy may be labelled a failure. Combining the traditional scientific approach which emphasises rationalism with the traditional constructivist approach which emphasises meaning and interpretation, McConnell (2010) defines a successful policy as the one, "which achieves the goals that proponents set out to achieve and attracts no criticism of any significance and/or support is virtually universal." Alternatively, Pawson (2006) defines a successful public policy as the one which is inclusive or which involves stakeholders and redresses inequality.

The central part of these definitions is the importance of support in policy success. Both definitions indicate that a successful policy is the one with no criticism or the one with significant support. Then the question is why do policies derived from Manifestos of democratically elected political parties sometimes fail. The transmission of a majority vote from national elections to policy success is not well documented in literature. Existing studies on policy evaluation do not explain the paradoxical link between winning an election resoundingly and the subsequent policy failures experienced in some countries. If policy success if defined by the level of support then in democratic elections, a winning party is likely to implement successful policies. But this has not been the case in a number of countries as discussed in the introduction. Although the three policy strands, process, programs and politics, emphasize engagements and resolving controversies (McConnell, 2010; Bardach, 2009 and Gastil, 2008), there is no clear explanation as to why a ruling majority government cannot easily engage and avoid policy failure.

Public policy evaluation approach is both ex ante and ex post although ex post studies are more dominant than ex ante studies. The ex ante public policy evaluation assesses the likely impacts of a policy before implementation whereas the ex post evaluates the impact of the policy after implementation. While the ex post evaluation provides useful lessons to policy makers in preparation of redesigning future policies, it is costly in the case of failures. Ex ante policy evaluation may help in reducing incidences of policy failure since policy makers are advised about the potential impact of a policy before its implementation. So, in cases where failure is likely to occur, they can redesign the policy or avoid it. McConnell (2010) argues that a good policy design relies on ex ante policy evaluation, rather than relying simply on ex post policy evaluation to claim success or failure. The theory proposed in this article is an ex ante approach in public policy evaluation. Like cost-benefit analysis of a proposed investment, ex ante evaluation in public policy informs decision makers in policy implementation and in the designing of policy instrument. Whereas previous studies argue that what constitute policy success/failure is mainly subjective (see Howlett et al., 2015 and Wildavsky, 1987) and suggest qualitative solutions as to how governments can overcome failure (Howlett, 2012), the proposed theory in this article attempts to provide a measurable or quantifiable driver of policy success or failure. A quantitative measure of policy success or failure provides a partial solution to McConnell (2010)'s argument that policy analysis has lacked a framework that allows policy evaluators to capture the 
various outcomes from success to failure in the process, program and political policy strands.

Out of the three policy failure strands (process failure, program failure and political failure) discussed in McConnell (2010) and Howlett (2012), process and political failures are more critical in poor countries. For instance, in many African countries where policies have been claimed to have failed, the question of political legitimacy has been the major issue. Howlett (2012) contends that the roles played by process and political problems in policy failure are under-appreciated and there is therefore need to draw more lessons from the two in order to enhance the chances of policy success. It is in this respect that the theory discussed in this article is significantly derived from process and political problems. While previous studies on policy evaluation extensively discuss how politics subjectively shape policy outcome claims (Fischer, 2003 and Wildavsky, 1987), the theory explained in this article considers the political sphere as an objective element of the process that shapes the outcomes in public policy. Questions on how programs fail are also addressed by the proposed theory and the resultant model. In general, the theory supplements and supports previous studies on policy evaluation through the provision of objective answers as to why public policies implemented by a democratically elected government sometimes fail despite having a majority support.

\section{Political process of policy formulation and the paradox of a majority vote}

Policy formulation is a process that is usually initiated by political parties during an election campaign, mainly presented in the form of a political Manifesto. Political parties compete and sell their ideas to the public during election campaigns. It is during this phase in which economic policies are initiated. A winning political party will then form a government which takes responsibility of policy formulation and implementation during the next political tenure. These policies are usually tailor-made to support the promises made to citizens during the period of election campaign. The direction taken by implemented economic policies is largely shaped by the behaviour of economic actors. It is the influence of these economic actors which directs policy outcomes towards either success or failure. Figure 1 illustrates the political process of policy formulation as a cycle.

Figure 1: The political process of policy formulation

\begin{tabular}{|l|l|l|l|l|}
\hline $\begin{array}{l}\text { Election campaign/electorate } \\
\text { Development and selling } \\
\text { of political parties' ideas } \\
\text { and policies in Manifestos }\end{array}$ & $\begin{array}{l}\text { Political } \\
\text { Actors/Majority }\end{array}$ & $\begin{array}{l}\text { Winning Party } \\
\text { Formulation and implementation } \\
\text { of policies customized to address } \\
\text { policy issues in the Manifesto }\end{array}$ \\
\hline
\end{tabular}


Political parties develop Manifestos as a campaigning instrument and voters usually select the party they think has their best interests on the basis of these Manifestos. Consider a country with two political parties and a population of $N$ voters in which the democratically elected party has $S$ political supporters who vote for the party and the remainder, $N-S$ voters, are for the political opponent. The ratio of supporting to opposing political actors $(P R)$ is:

$$
P R=\frac{S}{N-S}>1(\text { since } S>N-S)
$$

With this ratio, the winning majority party takes monopoly control of policy formulation and implementation. In order to fulfill its promises to the voters, the winning party usually derive and implements policies provided in its election Manifesto. However, when a policy is implemented, actions of economic agents (business owners, dealers, speculators and other economically influential individuals) shape the direction and outcomes of a given policy. If the total number of economic actors with influence on policy changes is $E A$ and the number of policy supporters is $E S$, then the number of policy opponents, $E A-E S$, is the size of policy friction/resistance, which we refer to as $F$ in this article. Therefore, the size of economic policy support per unit of friction $(F)$ can be expressed as:

$$
\delta=\frac{E S}{F}
$$

With homogeneous economic actors (agents with the same weight in influencing policy outcomes), a policy will only be successful if support exceeds friction, that is, if support per unit of friction is greater than 1. Compactly, the necessary condition for a successful policy with homogeneous economic actors is $\delta>1$. A number of resoundingly winning political parties in poor countries perceive that the ratio of their party supporters in an election is the same across political and economic divides. So, in this case where the political ratio (the ratio of winning party supporters) is constant even in the economic actors' group then:

$$
\delta=\frac{E S}{F}=\frac{S}{N-S}>1
$$

If the perception is true, then there will be more forces pushing the policy outcomes towards the target than forces pulling outcomes away from the target. Although the result in equation (3) is generally expected, evidence from previous winning political parties in poor countries show otherwise (see Besada \& Moyo, 2008). Democratically elected governments have found themselves in a predicament of policy failures $(\delta<1)$, where friction is relatively bigger than support, despite commanding a relatively larger support base. This is referred to as the paradox of a majority vote in policy evaluation in this article. 
The paradox is a result of heterogeneous voters across groups. Voters are not homogeneous in terms of their influence on the economy or economic policies. A political party can resoundingly win a national election but might also have less influential supporters in the economic arena. This is quite common in countries where urban areas are the opposition strongholds. Urban areas accommodate business persons, speculators and more educated persons who dominate economic activities that shape the direction of a policy. A policy is likely to fail in cases where there is greater opposition to a policy than support from these groups. In other words, a condition for policy failure is that policy friction or resistance exceeds policy support, that is, $F>E S$. The impact of a policy opponent or supporter on the final policy outcome generally depends on the opponent/supporter's weight in the economy. A government may have fewer opponents to its policies but with larger impact on the economy which leads to policy failure or less supporters with larger impact on the economy which leads to policy success. Achieving the policy outcome $(\tau)$ is therefore a function of the weight of policy support and the weight of friction. We therefore present the policy outcome $\tau$ as a product of support and the inverse of resistance or friction of the form:

$$
\tau=E S^{\theta} F^{-\beta}
$$

where $\tau, E S$ and $F$ are defined as above, $\theta$ is the weight of policy supporters in the economy and $\beta$ is the weight of friction or the weight of policy opponents in the economy. Alternatively, through linearization of equation (4), $\theta$ can be considered as a measure of the responsiveness of policy outcomes to changes in policy support while $\beta$ as the responsiveness of policy outcomes to a percentage change in friction. The linear form of equation (4) is expressed as:

$$
\begin{aligned}
& \ln \tau=\theta \ln E S-\beta \ln F \\
& \frac{1}{\tau} \partial \tau=\frac{\theta}{E S} \partial E S-\frac{\beta}{F} \partial F
\end{aligned}
$$

From partial derivatives, we obtain the following formulae for $\theta$ and $\beta$ which are measures of elasticities of policy outcome to changes in policy support and friction, respectively:

$$
\theta=\frac{\partial \tau}{\partial E S} \frac{E S}{\tau} \text { and } \beta=-\frac{\partial \tau}{\partial F} \frac{F}{\tau}
$$

Generally, $\tau$ can be thought as an indicator variable for policy outcome. Alternatively, it can be thought as a measure of policy defense from resistance forces. It provides the degree of policy support per unit of resistance or friction. When $\tau$ exceeds 1 , it means supporting forces exceed frictional or resistance forces. A value of $\tau$ below 1 implies greater friction relative to support. The former is a condition of policy success while the later illustrates a condition of policy failure. Measuring the number and weight of policy supporters and policy opponents within economic actors' group is not an easy task. However, the share of urban supporters who voted for the ruling 
party can provide a good proxy for $E S$ and $F$. In countries where there is no significant heterogeneity amongst voters in various areas, the percentage vote for the ruling party in a national election can also provide a good proxy for $E S$ and $F$. In poor countries, the most educated and business managers mostly reside in urban areas while the rural electorate is less influential in policy change. Hence, in countries where the opposition has a strong urban support base, policy friction may be relatively higher.

In Table 1, we present a simplified example of how the paradox of majority vote occurs. Consider a political party winning resoundingly in an election with $51 \%$ of the national vote and the opposition taking $49 \%$. Simulations of six scenarios are provided in the Table. One can try as many scenarios as possible.

Table 1: Simplified scenario simulations

\begin{tabular}{lrrrrrrr}
\hline Scenario & $\boldsymbol{E S}$ & $\boldsymbol{F}$ & $\boldsymbol{\theta}$ & $\boldsymbol{\beta}$ & $\boldsymbol{E S}^{\boldsymbol{\theta}}$ & $\boldsymbol{F}^{-\boldsymbol{\beta}}$ & $\boldsymbol{\tau}$ \\
\hline $\mathbf{A}$ & 51 & 49 & 0.51 & 0.49 & 7.4278 & 6.7328 & 1.1032 \\
B & 51 & 49 & 0.50 & 0.50 & 7.1414 & 7.0000 & 1.0202 \\
C & 51 & 49 & 0.49 & 0.51 & 6.8661 & 7.2778 & 0.9434 \\
D & 49 & 51 & 0.50 & 0.50 & 7.0000 & 7.1414 & 0.9802 \\
E & 45 & 55 & 0.50 & 0.50 & 6.7082 & 7.4162 & 0.9045 \\
F & 45 & 55 & 0.45 & 0.55 & 5.5456 & 9.0615 & 0.6120 \\
\hline
\end{tabular}

In scenario $\mathrm{A}$, the democratically elected party has the same share of supporters in the economic actors' group as in the national electorate (51\%). Assuming that the weight of supporters of the elected party remain 0.51 as in the national election and as in the economic actors' group, the policy outcome index will be equal to 1.1032, greater than one. A policy is therefore likely to be successful because there will be a greater pressure for policy success than policy failure. This is the expected situation with no paradoxical outcomes. Most governments in poor countries usually ignore the opposition forces after democratically elected into power because of the assumption that the distribution of voters according to political parties remain the same in every group of the economy, as in scenario A. Scenario B demonstrates a similar situation as in scenario A except that the weight of policy supporters is the same as the weight of policy opponents. Similarly, a policy is likely to be successful as long as the ruling party commands a larger share of economic supporters.

There are, however, several scenarios that may cause the policy outcome index, $\boldsymbol{\tau}$, to have a value below one and in this article we have just considered four scenarios. In scenario $\mathrm{C}$, the democratically elected party with $51 \%$ of the national vote continues to have the same share of supporters in the economic actors' group. But, the economic supporters have a smaller weight of 0.49 in the economy compared to the opponents' weight of 0.51 . In this case, there is greater resistance to policy than support, despite commanding a majority in both the political and economic groups. The value of the policy outcome index is less than 1, a condition for policy failure. This is common where the opposition party has supporters from large businesses and dealers with significant impact on the economy. In scenarios $\mathrm{D}, \mathrm{E}$ and $\mathrm{F}$, the ruling government has 
resoundingly won the national election with $51 \%$ of the vote but commands less support in the economic actors' group. In D and E, the government has a lower share of economic supporters, nevertheless policy supporters have the same weight as that of opponents. In both cases, the policy outcome index remains less than one. The most severe cause of the paradox of majority vote in policy evaluation is a situation where the elected government has both a lower share of influential economic supporters and more supporters with smaller weight in the economy; the case presented in scenario F. Governments demonstrated in scenario $\mathrm{F}$ experience more incidences of policy failure.

\section{Conclusion, theory implications and suggested solutions to the paradox}

A number of lessons and implications can be derived from this theory. First, winning a political election is not a ticket for winning an economic war. A democratically elected government may have more opponents in the economic war front, despite having the most popular Manifesto amongst voters. Under this circumstance, there will be greater resistance/friction to implemented policies; a breeding ground for policy failures. Second, the quality of political supporters matter in economic management. If the political supporters of a democratically elected government possess at least the same economic influence as their political influence, then it will be easier for the ruling party to push for successful policies. Generally, support from a more educated and business oriented electorate benefits the democratically elected party in reducing incidences of policy failure. Economic supporters will always tailor make their activities to push the policy outcomes towards the government's target. Third, incidences of policy failure may be significantly reduced if the two political groups (winners and losers) come together and have some form of consensus on policy direction after a major national election. In other words, political dialogue after a major national election is a noble tool for managing incidences of policy failures.

A democratically elected government can considerably reduce incidences of policy failures through conversion of economic policy resistance $(F)$ into economic policy support (ES) or through reducing $\beta$ and increasing $\theta$. This can be done through, first, appointing level headed and apolitical government executives who command respect from some pockets of the opposition. The appointed executives can persuade business oriented political opponents to support government policies. Second, the government can identify economic policy opponents, specifically those with strong influence in the economy, and persuade them to support government policies. Incentives may be provided to turn this group into policy supporters. This option is, however, costly to the government. There is cost associated with the identification of influential policy opponents and the presence of information asymmetry lead to inefficient outcomes. For instance, when approached, an influential policy opponent will only accept a contract to support the government policy if the perceived benefit provided by the negotiator exceeds the expected benefit of increased opposition support due to government failure. This is more like a principal-agent problem which governments cannot usually consider as a possible option. Third, a political dialogue with the main opposition party can convert policy resistance into policy support. The government can easily convert policy 
opponents through turning the leader of opposition into supporting government policies. This approach is less costly than negotiating with every influential opponent. If the leader of the main opposition political party is persuaded to support government policies, then there is high likelihood that a significant number of his/her followers will do the same. The main implication of this point is that a meaningful political dialogue is the one that brings together the major political opponents in an economy. Last but not least is the importance of inclusivity in policy formulation processes. Government can significantly reduce incidences of policy failure through wide consultations that include the opposition as well.

\section{References}

Bardach, E. 2009. A Practical Guide for Policy Analysis: The Eightfold Path to more Effective Problem Solving, Third Edition. Washington, DC: CQ Press.

Besada, H. \& Moyo, N. 2008. Zimbabwe in Crisis: Mugabe's Policies and Failures. Working Paper No. 38. Waterloo, Ontario: The Centre for International Governance Innovation.

Dunleavy, P. 1995. "Policy Disasters: Explaining the UK's Record." Public Policy and Administration, 10 (2): 52-70.

Fischer, F. 2003. Reframing Public Policy: Discursive Politics and Deliberative Practices. Oxford: Oxford University Press.

Gastil, J. 2008. Political Communication and Deliberation. Thousand Oaks, CA: Sage.

Gupta, D. \& Sathye, M. 2009. "Turnaround of the Indian Railways: A Public Ownership Saga." International Journal of Public Policy, 5 (1): 86-102.

Handmer, J. \& Dovers, S. 2007. Handbook of Disaster and Emergency Policies and Institutions. London: Earthscan.

Hill, M. \& Hupe, P. 2009. Implementing Public Policy, Second Edition. London: Sage.

Hindmoor, A. \& McConnell, A. 2013. “Why didn't they see it coming? Warning Signs, Acceptable Risks and the Global Financial Crisis. Political Studies, 61 (3): 543-560.

Howlett, M., Ramesh, M. \& Wu, X. 2015. “Understanding the Persistence of Policy Failures: The Role of Politics, Governance and Uncertainty." Public Policy and Administration, 30 (3-4): 209-220.

Howlett, M. 2012. "The Lessons of Failure: Learning and Blame Avoidance in Public Policymaking." International Political Science Review, 33 (5): 539-555.

McConnell, A. 2010. "Policy Success, Policy Failure and Grey Areas In-Between." Journal of Public Policy 30 (3): 345-362.

Minister of Finance. 2013. Update of Zimbabwe's Financial Position. Harare: Ministry of Finance.

Pawson, R. 2006. Evidence-based Policy: A Realist Perspective. London: Sage.

Pollack H. 2007. "Learning to Walk Slow: America's Partial Policy Success in the Arena of Intellectual Disability." Journal of Policy History, 19 (1): 95-112.

RBZ (Reserve Bank of Zimbabwe). 2018. Monetary Policy Statement. Harare: The Government of Zimbabwe. 
Schneider, A. L. \& Ingram, H. 1997. Policy Design for Democracy. Kansas: University Press of Kansas.

Sibanda, G. 2019. "RBZ Calls for Efficient Interbank Market." The Herald, May 21. https:// www.herald.co.zw/rbz-calls-for-efficient-interbank-market/

Southall, R. J. 2018. "Bond Notes, Borrowing, and Heading for Bust: Zimbabwe's Persistent Crisis." Canadian Journal of African Studies, 51 (3): 389-405.

UNDP. 2010. Assessment of Development Results: Evaluation of UNDP Contribution in Zambia. Washington DC: UNDP Evaluation Office.

Uganda Bureau of Statistics (UBS). 2011. Ugandan Consumer Price Index. Kampala: The Government of Uganda. www.ubos.org.

Walsh, J. I. 2006. "Policy Failure and Policy Change: British Security Policy after the Cold War." Comparative Political Studies, 39 (4): 490-518.

Wildavsky, A. 1987. Speaking Truth to Power: The Art and Craft of Policy Analysis. Second Edition. New Brunswick: Transaction.

ZIMSTAT. 2019. The Consumer Price Index. Harare: The Government of Zimbabwe.

ZIMSTAT. 2013. National Income Accounts. Harare: The Government of Zimbabwe. 